\title{
Extensive analysis of native and non-native Centaurea solstitialis L. populations across the world shows no traces of polyploidization
}

\author{
Ramona-Elena Irimia ${ }^{\text {Corresp., }}{ }^{1,2}{ }^{2}$, Daniel Montesinos ${ }^{1}$ ， Özkan Eren ${ }^{3}$, Christopher J Lortie ${ }^{4}$, Kristine French ${ }^{5}$ \\ Lohengrin A Cavieres ${ }^{6,7}$ ， Gastón J Sotes ${ }^{6,7}$ ， José L Hierro ${ }^{8}$ ， Andreia Jorge ${ }^{1}$ ， João Loureiro ${ }^{1}$ \\ ${ }^{1}$ Centre for Functional Ecology, Department of Life Sciences, University of Coimbra, Coimbra, Portugal \\ 3 Adnan Menderes Üniversitesi, Fen-Edebiyat Fakültesi, Biyoloji Bölümü, Aydın, Turkey \\ 4 Department of Biology, York University, Toronto, Canada \\ 5 School of Biological Sciences, University of Wollongong, Wollongong, Australia \\ 6 Departamento de Botánica, Facultad de Ciencias Naturales y Oceanográficas, Universidad de Concepción, Concepción, Chile \\ 7 Instituto de Ecología y Biodiversidad (IEB), Santiago, Chile \\ 8 Instituto de Ciencias de La Tierra y Ambientales de la Pampa, Consejo Nacional de Investigaciones Científicas y Técnicas (INCITAP-CONICET) and \\ Facultad de Ciencias Exactas y Naturales, Universidad Nacional de La Pampa, Santa Rosa, Argentina \\ Corresponding Author: Ramona-Elena Irimia \\ Email address: ramonaeirimia@gmail.com
}

Centaurea solstitialis L. (yellow starthistle, Asteraceae) is a Eurasian native plant introduced as an exotic into North and South America, and Australia, where it is regarded as a noxious invasive. Changes in ploidy level have been found to be responsible for numerous plant biological invasions, as they are involved in trait shifts critical to invasive success, like increased growth rate and biomass, longer life-span, or polycarpy. $C$. solstitialis had been reported to be diploid ( $2 n=2 x=16$ chromosomes), however, actual data are scarce and sometimes contradictory. We determined for the first time the absolute nuclear DNA content by flow cytometry and estimated ploidy level in 52 natural populations of $C$. solstitialis across its native and non-native ranges, around the world. All the $\mathrm{C}$. solstitialis populations screened were found to be homogeneously diploid (average $2 \mathrm{C}$ value of $1.72 \mathrm{pg}, \mathrm{SD}= \pm 0.06 \mathrm{pg}$ ), with no significant variation in DNA content between invasive and non-invasive genotypes. We did not find any meaningful difference among the extensive number of native and non-native $C$. solstitialis populations sampled around the globe, indicating that the species invasive success is not due to changes in genome size or ploidy level. 


\section{Extensive analysis of native and non-native Centaurea solstitialis $\mathbf{L}$.}

\section{2 populations across the world shows no traces of polyploidization}

3

4 Ramona-Elena Irimia ${ }^{1,2}$, Daniel Montesinos ${ }^{1}$, Özkan Eren ${ }^{3}$, Christopher J. Lortie ${ }^{4}$, Kristine 5 French $^{5}$, Lohengrin A. Cavieres ${ }^{6,7}$, Gastón J. Sotes ${ }^{6,7}$, José L. Hierro ${ }^{8}$, Andreia Jorge ${ }^{1}$ and 6 João Loureiro ${ }^{1}$ 7

${ }^{1}$ Centre for Functional Ecology, Department of Life Sciences, University of Coimbra, Coimbra, Portugal

${ }^{2}$ National Institute of Research and Development for Biological Sciences, Stejarul Research Centre for Biological Sciences, Piatra Neamţ, Romania

${ }^{3}$ Adnan Menderes Üniversitesi, Fen-Edebiyat Fakültesi, Biyoloji Bölümü, Aydın, Turkey

${ }^{4}$ Department of Biology, York University, Toronto, Canada

${ }^{5}$ School of Biological Sciences, University of Wollongong, Wollongong, Australia

${ }^{6}$ Departamento de Botánica, Facultad de Ciencias Naturales y Oceanográficas, Universidad de Concepción, Concepción, Chile

${ }^{7}$ Instituto de Ecología y Biodiversidad (IEB), Santiago, Chile

${ }^{8}$ Instituto de Ciencias de La Tierra y Ambientales de la Pampa, Consejo Nacional de Investigaciones Científicas y Técnicas (INCITAP-CONICET) and Facultad de Ciencias Exactas y Naturales, Universidad Nacional de La Pampa, Santa Rosa, Argentina

Corresponding Author:

Ramona-Elena Irimia, ramonaeirimia@gmail.com 


\section{ABSTRACT}

9 Background. Centaurea solstitialis L. (yellow starthistle, Asteraceae) is a Eurasian native plant

10 introduced as an exotic into North and South America, and Australia, where it is regarded as a

11 noxious invasive. Changes in ploidy level have been found to be responsible for numerous plant

12 biological invasions, as they are involved in trait shifts critical to invasive success, like increased

13 growth rate and biomass, longer life-span, or polycarpy. C. solstitialis had been reported to be

14 diploid $(2 \mathrm{n}=2 x=16$ chromosomes $)$, however, actual data are scarce and sometimes

15 contradictory. Methods. We determined for the first time the absolute nuclear DNA content by

16 flow cytometry and estimated ploidy level in 52 natural populations of $C$. solstitialis across its

17 native and non-native ranges, around the world. Results. All the C. solstitialis populations

18 screened were found to be homogeneously diploid (average $2 \mathrm{C}$ value of $1.72 \mathrm{pg}, \mathrm{SD}= \pm 0.06 \mathrm{pg}$ )

19 with no significant variation in DNA content between invasive and non-invasive genotypes.

20 Discussion. We did not find any meaningful difference among the extensive number of native

21 and non-native $C$. solstitialis populations sampled around the globe, indicating that the species

22 invasive success is not due to changes in genome size or ploidy level.

23

24 Subjects Plant Science, Biogeography, Evolutionary Studies

25 Keywords Yellow starthistle, Invasiveness, Genome size, Flow cytometry, Ploidy level,

26 Hybridization 


\section{INTRODUCTION}

32 Changes in ploidy level have been reported to be important for the invasive success of some

33 plants species (te Beest et al., 2011), by altering morphological, physiological and ecological

34 parameters which can confer hybrid vigor, stress resistance, competitive advantages, or increased

35 phenotypic plasticity, like in the case of the North American tetraploids of Centaurea stoebe L.

36 (Hahn et al., 2012). Additionally, there are a series of associated "genome size constrained

37 traits", related mostly to reproduction and dispersal, which dictate the ecological niche a species

38 can access (te Beest et al., 2011). In contrast, several studies support the hypothesis that a

39 smaller genome can contribute to some species invasive potential by boosting early plant growth

40 and enhancing competitive ability (Bennett et al., 1998; Grotkopp et al., 2004; Beaulieu et al.,

41 2006; Lavergne et al., 2010; Suda et al., 2015). For instance, Phalaris arundinacea L. (reed

42 canary grass, Poaceae) in the USA underwent a quick and significant reduction in genome size

43 compared to the native European genotype, which was correlated with some advantageous

44 phenotypic effects and enhanced aggressiveness (Lavergne et al., 2010). A list comparing the

45 ploidy level of 128 worst invasive plant species worldwide, was recently made available by te

46 Beest et al. (2011), indicating that a quarter of them possess at least two different ploidy levels.

47 An interesting example is C. stoebe (spotted knapweed) which occurs both as a diploid and

48 tetraploid, with only the latter cytotype becoming invasive in the Western parts of the USA

49 (Mráz et al., 2011). Although there is still ongoing debate about the prevalence of polyploids

50 among plant species, it has been recently inferred that polyploidy has had a key role in the

51 evolution of most angiosperm lineages (Soltis et al., 2009). However, for many invasive species,

52 ploidy levels and genome size are unknown or have not been thoroughly investigated. 
54 Numerous Centaurea species have been introduced into new non-native regions, where many of

55 them have become invasive. For instance, the US Federal Noxious Weeds list (USDA NRCS,

56 The PLANTS Database, 2017), includes no fewer than 13 taxa, but ploidy level for many of

57 these is unknown or uncertain. In particular, C. solstitialis is a Eurasian native annual herb

58 which was introduced into the Americas and Australia during the last two centuries (Barker et

59 al., 2017) and became an impactful invader in the former case. In the invaded ranges, $C$.

60 solstitialis forms dense stands that displace native plants species and reduce considerably

61 livestock grazing capacity and forage value (Eagle et al., 2007). It alters ecosystem functions by

62 depleting soil water and nutrients through an extensive root system (DiTomaso, 2000), and can

63 cause a neurological disorder in horses similar to human Parkinson (Chang et al., 2011). As an

64 economically important plant, the species has been the subject of intensive research, and

65 significant divergences between native and non-native ranges have been reported for plant size

66 (Eriksen et al., 2012; Graebner et al., 2012; García et al., 2013; Dlugosch et al., 2015), growth

67 rates (Graebner et al., 2012), germination (Hierro et al., 2009), competitive ability (Montesinos

68 \& Callaway, 2017), and reproduction (Montesinos et al., 2012), among others. Such changes

69 suggest diverging local adaptation occurring among native and non-native ranges, and

70 hypothetical changes in genome size and ploidy level could be potentially responsible for at least

71 some of the observed trait-shifts.

72 Until now, only three genome size estimates were available in the literature for $C$.

73 solstitialis: two from the native range (Bulgaria: $1.74 \mathrm{pg} / 2 \mathrm{C}$, one accession, in Bancheva \&

74 Greilhuber 2006; and Croatia: 1.95 pg/2C, five accessions, in Carev et al., 2017) and another

75 from an invasive population in western USA: $1.66 \mathrm{pg} / 2 \mathrm{C}$, thirty accessions (Miskella, 2014). 
76 Based on these few studies, $C$. solstitialis had been reported to be diploid (Dlugosch et al., 2013;

77 Rice et al., 2015) with $2 \mathrm{n}=2 \mathrm{x}=16$ chromosomes. However, records of $2 \mathrm{n}=2 \mathrm{x}=18$

78 chromosomes were published more than 30 years ago from the native range of Bulgaria

79 (Jasiewicz \& Mizianty, 1975; Kuzmanov \& Georgieva, 1990) and recently from one accession

80 from Sicily and the other one from Sardinia (Widmer et al., 2007). Furthermore, Inceer et al.

81 (2007) reported tetraploids in seeds (single accession) sampled in northern Turkey, but none of

82 those observations, made in only a handful of individuals, have been confirmed since then.

83 Consequently, it was still unclear whether ploidy could have played a role in at least some of the

84 C. solstitialis invaded ranges. To fill this knowledge gap for such an important species, we

85 aimed to thoroughly sample and assess C. solstitialis ploidy level and genome size in a

86 representative number of populations from around the world, including native Turkey, the

87 ancestral origin of the species; native Spain, the main source of American populations; and all

88 the known non-native regions represented by Argentina, Chile, USA and Australia.

\section{METHODS}

\section{Seed collection}

92 A total of 477 accessions from 52 natural populations (Table S1) of C. solstitialis were

93 investigated in this study, for genome size and ploidy level assessment. Within the native area,

94 we sampled ten populations from Turkey, near the Caucasus region, where high genetic diversity

95 has been detected, and is regarded as the site of origin of the species(Wagenitz, 1955; Gerlach,

96 1997a; Uygur et al., 2004; Dlugosch et al., 2013; Eriksen et al., 2014), and ten populations from

97 Spain, considered as the primary source of seeds to have colonized Chile and Argentina (Hijano

98 \& Basigalup, 1995; Eriksen et al., 2012, 2014; Dlugosch et al., 2013; Barker et al., 2017) in the 
99 nineteenth century (Gerlach, 1997b). For the non-native regions, we included ten populations

100 from Argentina and California, eight from Australia and four from Chile. Seeds were extracted

101 from mature flower heads collected in the wild from ten individuals per population between 2009

102 and 2014. Ten seeds from each individual were germinated in plant growing trays, under

103 common greenhouse conditions, in early spring 2016 at the Botanical Garden of the University

104 of Coimbra, Portugal.

105

\section{Flow cytometry}

107 Young and intact leaves of 4-6 weeks-old plants were sampled and screened by flow cytometry.

108 Since analyses were based on leaves of small plants, which were destroyed by leaf sampling, no

109 voucher specimens could be collected. Nuclei were isolated following the chopping method of

110 Galbraith et al., 1983. Briefly, about $1 \mathrm{~cm}^{2}$ of leaf tissue was co-chopped with a razor blade

111 together with the same amount of reference standard (Raphanus sativus L. 'Saxa', 2C $=1.11 \mathrm{pg}$,

112 Doležel et al., 1992) in $1 \mathrm{~mL}$ of woody plant buffer (WPB): $0.2 \mathrm{M}$ Tris.HCl, $4 \mathrm{mM} \mathrm{MgCl} 2.6 \mathrm{H}_{2} \mathrm{O}$,

$1132 \mathrm{mM}$ EDTA $\mathrm{Na}_{2} \cdot 2 \mathrm{H}_{2} \mathrm{O}, 86 \mathrm{mM} \mathrm{NaCl}, 10 \mathrm{mM}$ sodium metabisulfite, $1 \% \mathrm{PVP}-10,1 \%$ (v/v)

114 Triton X-100, $\mathrm{pH} 7.5$ (Loureiro et al., 2007). The resulting homogenate was filtered through a

$11550 \mu \mathrm{m}$ nylon filter into a sample tube to remove large debris. Nuclei were stained with 50

$116 \mathrm{mg} / \mathrm{mL}$ propidium iodide (PI, Fluka, Buchs, Switzerland), and $50 \mathrm{mg} / \mathrm{ml}$ of RNAse (Fluka,

117 Buchs, Switzerland) was added to prevent the staining of double stranded RNA. Samples were

118 kept at room temperature and analyzed immediately on a Partec CyFlow Space flow cytometer

119 (Partec GmbH, Görlitz, Germany) equipped with a $532 \mathrm{~nm}$ green solid-state laser, operating at $12030 \mathrm{~mW}$. 


\section{Data collection and analysis}

123 Results were acquired using Partec FloMax software (v2.4d) (Partec GmbH, Münster, Germany)

124 in the form of six graphics: fluorescence pulse integral in linear scale (FL); forward light scatter

125 (FS) vs. side light scatter (SS), both in logarithmic (log) scale; FL vs. time; FL vs. fluorescence

126 pulse height; FL vs. FS in log scale and FL vs. SS in log scale. Mean fluorescence values and

127 coefficient of variation (CV value) of the fluorescence of both sample and standard were

128 obtained for at least 1300 nuclei in each $\mathrm{G}_{1}$ peak, whenever possible. Samples with CV values

129 above 5\% were discarded, prepared and ran again. At least three individuals from every

130 population were used to estimate genome size (Table S2), in different days, to account for the

131 variation generated by the flow cytometer. The remaining individuals were analyzed in pool

132 (three or four individuals) to determine ploidy level, only. The absolute DNA content of a

133 sample was calculated based on the following formula: $2 \mathrm{C}$ nuclear DNA content of the sample $=$

134 (sample $\mathrm{G}_{1}$ peak mean) / (standard $\mathrm{G}_{1}$ peak mean) $\times 2 \mathrm{C}$ DNA content of standard. Descriptive

135 statistics were calculated for genome size data (mean, standard deviation of the mean, standard

136 error, coefficient of variation and minimum and maximum values) using Microsoft Excel 2016.

137 Differences in average genome size values among regions were assessed by means of Linear

138 Mixed-Effect Models with the formulation of Laird and Ware (1982), with a region as fixed

139 factor and population within region as a random nested factor, in R-3.2.0 (R Development Core

140 Team, 2010). Data was plotted in BoxPlotR (Spitzer et al., 2014).

\section{RESULTS}

143 Analysis of fresh leaf tissue sampled from seedlings germinated from wild seeds of individuals

144 from 52 populations from Turkey, Spain, Argentina, Chile, USA and Australia (Table S1), 
145 showed no significant differences in genome size $\left(\mathrm{F}_{5,44}=0.58 ; \mathrm{p}=0.716\right)$ among regions (Fig. 1).

146 All individuals $(\mathrm{N}=477)$ were found to be diploid, presumably with $2 \mathrm{n}=16$ chromosomes.

147 Average genome size ranged from $1.70 \mathrm{pg} / 2 \mathrm{C}(\mathrm{SD}=0.06 \mathrm{pg})$ in Australia and Spain $(\mathrm{SD}=0.06$

$148 \mathrm{pg})$ to $1.71 \mathrm{pg} / 2 \mathrm{C}(\mathrm{SD}=0.06 \mathrm{pg})$ in Chile, $1.72 \mathrm{pg} / 2 \mathrm{C}(\mathrm{SD}=0.06 \mathrm{pg})$ in Argentina and

149 California $(\mathrm{SD}=0.07 \mathrm{pg})$ and $1.73 \mathrm{pg} / 2 \mathrm{C}(\mathrm{SD}=0.07 \mathrm{pg})$ in Turkey (Table 1).

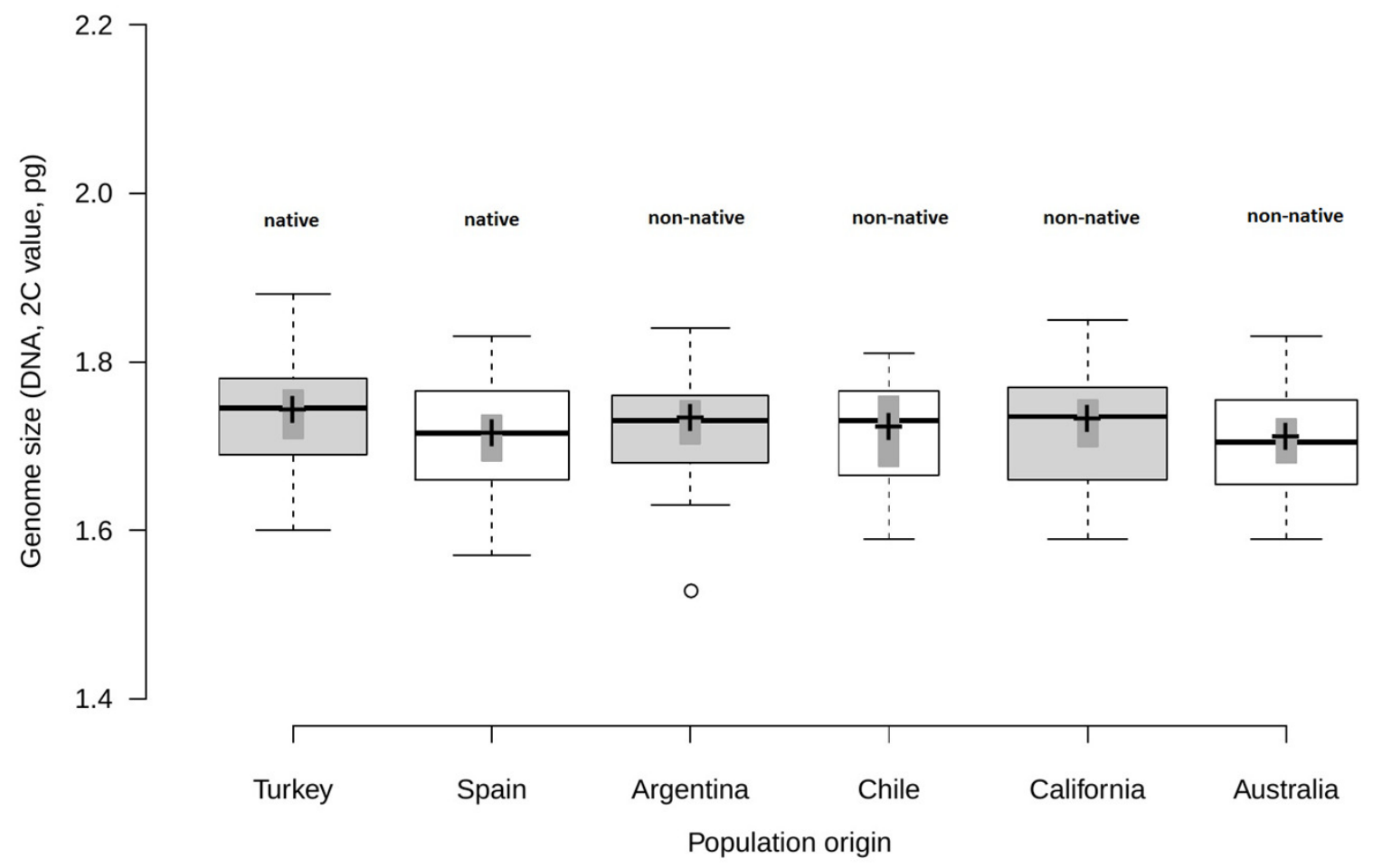

150

151 Figure 1: Comparison of genome size among native and non-native genotypes of Centaurea

152 solstitialis. Black center lines represent the medians, crosses indicate sample means, box limits

153 indicate the 25 th and 75 th percentiles, whiskers extend 1.5 times the interquartile range from the

15425 th and 75 th percentiles, bars show 95\% confidence intervals of the means and outliers are

155 represented by empty dots. Width of the boxes is proportional to the square root of sample size, $156 \mathrm{n}=26,28,29,12,30,24$ sample points. 
157 Table 1: Genome size estimations in Centaurea solstitialis across the six sampled regions.

\begin{tabular}{|c|c|c|c|c|c|c|}
\hline \multirow{2}{*}{ Region } & \multicolumn{5}{|c|}{ Genome size $(2 \mathrm{C}, \mathrm{pg})$} & \multirow{2}{*}{$\mathbf{N}$} \\
\hline & Mean & SD & SE & Min & Max & \\
\hline Argentina & 1.727 & 0.067 & 0.012 & 1.53 & 1.84 & 29 \\
\hline Australia & 1.705 & 0.061 & 0.012 & 1.59 & 1.83 & 24 \\
\hline California & 1.727 & 0.074 & 0.013 & 1.59 & 1.85 & 30 \\
\hline Chile & 1.717 & 0.065 & 0.018 & 1.59 & 1.81 & 12 \\
\hline Spain & 1.709 & 0.069 & 0.013 & 1.57 & 1.83 & 28 \\
\hline Turkey & 1.737 & 0.070 & 0.013 & 1.60 & 1.88 & 26 \\
\hline Total & 1.720 & 0.068 & 0.014 & 1.57 & 1.84 & 149 \\
\hline
\end{tabular}

158 Note: Values are given as mean, standard deviation and standard error of the mean. The

159 minimum and maximum values and the number of analyzed individuals $(\mathrm{N})$ for genome size

160 estimations are also provided.

161

162 Genome size variation among populations within regions (Table S1) was also not significantly

163 different, as indicated by very small standard deviations for the intercept and the residual

164 obtained for the random effects $\left(\mathrm{SD}_{\text {intercept }}=0.024 ; \mathrm{SD}_{\text {residual }}=0.063\right)$.

165

166

\section{DISCUSSION}

167 We found no traces of polyploidization events in the C. solstitialis populations investigated and 168 geographic differences in genome size were negligible.

A previous record of isolated tetraploids (one accession) in Northern Turkey (Inceer et

170 al., 2007) is intriguing, since further genomic sampling in the area (e.g., less than $40 \mathrm{~km}$ from the

171 initial site, Barker et al., 2017) did not validate the findings. Further investigation is also

172 required to clarify the reported putative hybridization (Barker et al., 2017) with Centaurea

173 nicaeensis L. $(2 \mathrm{n}=20$ chromosomes, Guinochet \& Foissac 1962), since inter-specific

174 hybridization does not seem to have played a significant role in the past invasion history of $C$.

175 solstitialis (Barker et al., 2017). Formerly, a single natural hybrid of Centaurea $\times$ moncktonii C.E. 
176 Britton and C. solstitialis was described from Oregon, USA (Roché \& Susanna 2010) and found

177 to be a sterile triploid (Miskella 2014).

178 The genome size value we obtained for California $(1.72 \mathrm{pg} / 2 \mathrm{C}, \mathrm{SD}=0.07 \mathrm{pg})$ was

179 similar to the one previously reported for Southwestern Oregon (1.66 pg/2C, SD = $0.07 \mathrm{pg}$, ) by

180 Miskella (2014) and, overall, genome sizes were similar among the six world regions.

181 In conclusion, our thorough sampling of the most representative native and non-native

182 populations across the world's distribution of $C$. solstitialis indicates that its invasive success is

183 not due to changes in genome size or ploidy level. We cannot discard that some individuals in

184 some unsampled populations could present some degree of polyploidy, but their role in invasive

185 success, to date, would have been of minor importance.

186

\section{ACKNOWLEDGMENTS}

188 We are grateful to Joan Vallès (Barcelona) and three other anonymous reviewers for their

189 valuable comments on the previous version of this manuscript.

190

191

\section{REFERENCES}

192

193

194

195

196

197

198

199

200

201

202

203

Bancheva S, Greilhuber J. 2006. Genome size in Bulgarian Centaurea s.1. (Asteraceae). Plant Systematics and Evolution 257:95-117. DOI 10.1007/s00606-005-0384-7.

Barker BS, Andonian K, Swope SM, Luster DG, Dlugosch KM. 2017. Population genomic analysis reveal a history of range expansion and trait evolution across the native and invaded range of yellow starthistle (Centaurea solstitialis). Molecular Ecology 26(4):1131-1147. DOI: 10.1111/mec.13998.

Beaulieu JM, Moles AT, Leitch IJ, Bennett MD, Dickie JB, Knight CA. 2007. Correlated evolution of genome size and seed mass. New Phytologist 173:422-437. DOI 10.1111/j.1469-8137.2006.01919.x.

Bennett MD, Leitch IJ, Hanson L. 1998. DNA amounts in two samples of angiosperm weeds. Annals of Botany 82(Supplement A):121-134. DOI 10.1006/anbo.1998.0785.

Bremer K. 1994. Asteraceae - cladistics and classification. Portland: Timber Press. 
204

205

206

207

208

209

210

211

212

213

214

215

216

217

218

219

220

221

222

223

224

225

226

227

228

229

230

231

232

233

234

235

236

237

238

239

240

241

242

243

244

245

246

247

248

249

Carev I, Ruščić M, Skočibušić M, Maravić A, Silijak-Yakovlev S, Politeo, O. 2017. Phytochemical and cytogenetic characterization of Centaurea solstitialis L. (Asteraceae) from Croatia. Chemistry and Biodiversity 14, e1600213. DOI:10.1002/cbdv.201600213.

Chang HT, Rumbeiha WK, Patterson JS, Puschner B. 2011. Toxic equine Parkinsonism: an immuno-histochemical study of 10 horses with nigropallidal encephalomalacia. Veterinary Pathology 49(2):398-402. DOI 10.1177/0300985811406885.

DiTomaso JM. 2000. Invasive weeds in rangelands: species, impacts, and management. Weed Science 48(2):255-265. DOI 10.1614/0043-1745(2000)048[0255:IWIRSI]2.0.CO;2.

Doležel J, Sgorbati S, Lucretti S. 1992. Comparison of three DNA fluorochromes for flow cytometric estimation of nuclear DNA content in plants. Physiologia Plantarum 85:625631. DOI 10.1111/j.1399-3054.1992.tb04764.x.

Dlugosch KM, Lai Z, Benin A, Hierro JL, Rieseberg LH. 2013. Allele identification for transcriptome based population genomics in the invasive plant Centaurea solstitialis. G3 Genes | Genomes | Genetics 3:359-367. DOI 10.1534/g3.112.003871.

Dlugosch KM, Cang FA, Barker BS, Andonian K, Swope SM, Rieseberg LH. 2015. Evolution of invasiveness through increased resource use in a vacant niche. Nature Plants 1:15066. DOI 10.1038/nplants.2015.66.

Eagle AJ, Eiswerth ME, Johnson WS, Schoenig SE, van Kooten CG. 2007. Costs and losses imposed on California ranchers by yellow starthistle. Rangeland Ecology \& Management 60:369-377. DOI 10.2111/1551-5028(2007)60[369:CALIOC]2.0.CO;2.

Eriksen RL, Desronvil T, Hierro JL, Kesseli R. 2012. Morphological differentiation in a common garden experiment among native and non-native specimens of the invasive weed yellow starthistle (Centaurea solstitialis). Biological Invasions 7:1459-1467. DOI 10.1007/s10530-012-0172-6.

Eriksen RL, Hierro JL, Eren O, Andonian K, Török K, Becerra PI, Montesinos D, Khetsuriani L, Diaconu A, Kesseli R. 2014. Dispersal pathways and genetic differentiation among worldwide populations of the invasive Centaurea solstitialis $\mathrm{L}$. (Asteraceae). PLoS One 9:e114786. DOI 10.1371/journal.pone.0114786.

Galbraith DW, Harkins KR, Maddox JM, Ayres NM, Sharma DP, Firoozabady E. 1983. Rapid flow cytometric analysis of the cell cycle in intact plant tissues. Science 220:10491051. DOI: $10.1126 /$ science.220.4601.1049.

García Y, Callaway RM, Diaconu A, Montesinos D. 2013. Invasive and non-invasive congeners show similar trait shifts between their same native and non-native ranges. PLoS One. 8:e82281. DOI 10.1371/journal.pone.0082281.

Gerlach JD. 1997a. How the west was lost: reconstructing the invasion dynamics of yellow starthistle and other plant invaders of western rangelands and natural areas. California Exotic Pest Plant Council, Symposium Proceedings 3:67-72.

Gerlach JD. 1997b. The introduction, dynamics of geographic range expansion and ecosystem effects of yellow starthistle (Centaurea solstitialis). Proceedings of Californian Weed Science Society 49:236-241.

Graebner RC, Callaway RM, Montesinos D. 2012. Invasive species grows faster, competes better, and shows greater evolution toward increased size and growth than exotic non-invasive congeners. Plant Ecology 213:545-553. DOI 10.1007/s11258-0120020-x.

Grotkopp E, Rejmánek M, Sanderson MJ, and Rost TL. 2004. Evolution of genome size in Pines (Pinus) and its life-history correlates: supertree analyses. Evolution 58:1705-1729. 
252

253

254

255

256

257

258

259

260

261

262

263

264

265

266

267

268

269

270

271

272

273

274

275

276

277

278

279

280

281

282

283

284

285

286

287

288

289

290

291

292

293

294

295

DOI 10.1554/03-545.

Guinochet M, Foissac J. 1962. Sur les Caryotypes de quelques espèces du genre Centaurea L. et leur signification taxonomique. Bulletin de la Société Botanique de France 109:373-389. DOI 10.1080/00378941.1962.10838114.

Hahn MA, Buckley YM, Müller-Schärer H. 2012. Increased population growth rate in invasive polyploid Centaurea stoebe in a common garden. Ecology Letters 15(9):947954. DOI 10.1111/j.1461-0248.2012.01813.x.

Hierro JL, Eren O, Khetsuriani L, Diaconu A, Török K, Andonian K, Kikodze D, Janoian L, Villarreal D, Estanga-Mollica ME, Callaway, RM. 2009. Germination responses of an invasive species in native and non-native ranges. Oikos 118:529-538. DOI 10.1111/j.1600-0706.2008.17283.x.

Hijano EH, Basigalup DH. 1995. El cultivo de la alfalfa en la República Argentina. In: Hijano EH and Navarro A, ed. La Alfalfa en la Argentina. INTA, Buenos Aires.13-18.

Inceer H, Hayirlioglu-Ayaz S, Ozcan M. 2007. Chromosome numbers of the twenty-two Turkish plant species. Caryologia 60:349-357. DOI 10.1080/00087114.2007.10797958.

Jasiewicz A, Mizianty M. 1975. Chromosome numbers of some Bulgarian plants. Fragmenta Floristica et Geobotanica 21(3):277-288.

Kuzmanov BA, Jurukova-Grancarova PD, Georgieva, SB. 1990. Chromosome numbers of Bulgarian angiosperms. Fitologiya (Sofia) 38:92.

Laird NNM, Ware JJH 1982. Random-effects models for longitudinal data. Biometrics 38(4):963-974.

Lavergne S, Muenke NJ, Molofsky J. 2010. Genome size reduction can trigger rapid phenotypic evolution in invasive plants. Annals of Botany 105:109-116. DOI 10.1093/aob/mcp271.

Loureiro J, Rodriguez E, Doležel J, Santos C. 2007. Two new nuclear isolation buffers for plant DNA flow cytometry: a test with 37 species. Annals of Botany 4:875-488. DOI 10.1093/aob/mcm 152 .

Miskella J. 2014. Hybridization between yellow starthistle (Centaurea solstitialis) and meadow knapweed (Centaurea×moncktonii). Master's Thesis. Oregon State University.

Montesinos D, Santiago G, Callaway RM. 2012. Neo-allopatry and rapid reproductive isolation. American Naturalist 180:529-533. DOI 10.1086/667585.

Montesinos D, Callaway, RM. 2017. Inter-regional hybrids of native and invasive Centaurea solstitialis display intermediate competitive ability. Ecography. DOI 10.1111/ecog.02653.

Mráz P, Garcia-Jacas N, Gex-Fabry E, Susanna A, Barres L, Müller-Schärer H. 2011. Allopolyploid origin of highly invasive Centaurea stoebe s.l. (Asteraceae). Molecular Phylogenetics and Evolution 62:612-623. DOI 10.1016/j.ympev.2011.11.006.

R Development Core Team. 2010. R: A Language and Environment for Statistical Computing. R Foundation for Statistical Computing. Vienna, Austria. Available at https://www.rproject.org/ (accessed 6 June 2017).

Rice A, Glick L, Abadi S, Einhorn M, Kopelman NM, Salman-Minkov A, Mayzel J, Chay O, Mayrose I. 2015. The Chromosome Counts Database (CCDB) - a community resource of plant chromosome numbers. New Phytologist 206:19-26. DOI 10.1111/nhp.13191.

Roché CT, Susanna A. 2010. New habitats, new menaces: Centaurea $\times$ kleinii (C. moncktonii× C. solstitialis), a new hybrid species between two alien weeds. Collectanea Botanica 29 
:17-23. DOI 10.3989/collectbot.2010.v29.002.

Soltis DE, Albert VA, Leebens-Mack J, Bell CD, Paterson AH, Zheng C, Sankoff D, dePamphilis CW, Wall PK, Soltis PS. 2009. Polyploidy and angiosperm diversification. American Journal of Botany 96(1):336-348. DOI 10.3732/ajb.0800079.

Spitzer M, Wildenhain J, Rappsilber J, Tyres M. 2014. BoxPlotR: a web tool for generation of box plots. Nature Methods 11:121-122. DOI 10.1038/nmeth.2811.

Suda J, Meyerson LA, Leitch IJ, Pyšek P. 2015. The hidden side of plant invasions: the role of genome size. New Phytologist 205: 994-1007. DOI 10.1111/nph.13107.

te Beest M, Le Roux JJ, Richardson DM, Brysting AK, Suda J, Kubešová M, Pyšek P. 2011. The more the better? The role of polyploidy in facilitating plant invasions. Annals of Botany 109:19-45. DOI 10.1093/aob/mcr277.

USDA, NRCS. The PLANTS Database. 2017. National Plant Data Team, Greensboro. Available at http://plants.usda.gov (accessed 10 January 2017).

Uygur S, Smith L, Nezihi Uygur F, Cristofaro M, Balciunas J. 2004. Population densities of yellow starthistle (Centaurea solstitialis) in Turkey. Weed Science 52:746753. DOI 10.1614/WS-03-150R1.

Wagenitz C. 1955. Pollenmorphologie and Systematik in der gattung Centaurea L. s.l. Flora 142:213-275.

Widmer, TL, Guermache FG, Dolgovskaia MY, Reznik SY. 2007. Enhanced growth and seed properties in introduced vs. native populations of yellow starthistle (Centaurea solstitialis). Weed Science 55:465-473. DOI 10.1614/WS-06-211R1. 